\title{
EFFECT OF THE KOZAK SEQUENCE ON SEROCONVERSION OF MICE IMMUNIZED WITH A DNA VACCINE AGAINST SWINE COLIBACILOSIS
}

\author{
André Michelon ${ }^{1,2 *}$; Marcelo Michelon ${ }^{1}$; Simone Simionatto ${ }^{1}$; Valeska Lizzi Lagranha ${ }^{1 *}$; \\ Fabrício Rochedo Conceição ${ }^{1}$; Eliana Knackfus Vaz $^{3}$; Gustavo Maia Cerqueira ${ }^{1}$; Odir Antonio Dellagostin ${ }^{1}$
}

${ }^{1}$ Centro de Biotecnologia, Universidade Federal de Pelotas, Campus Universitário Capão do Leão, Pelotas, RS, Brasil. ${ }^{2}$ Programa de Pós-Graduação em Veterinária, Universidade Federal de Pelotas, Pelotas, RS, Brasil. ${ }^{3} \mathrm{CAV} / \mathrm{UDESC}$, Lages, SC, Brasil.

This paper corresponds to an "extended abstract" selected for oral presentation in the $22^{\text {nd }}$ Brazilian Congress of Microbiology, held in Florianópolis, SC, Brazil, in November 17-20, 2003

\begin{abstract}
The neonatal diarrhea in swine caused by enterotoxigenic Escherichia coli (ETEC) is responsible for high mortality and low growth rate in pigs and it is mainly dependent on the capacity of $E$. coli to attach to the surface of the small intestine, a property mediated by fimbria. In this study the faeC gene, which codes for the minor fimbrial subunit of $E$. coli $\mathrm{K} 88 \mathrm{ab}$, was cloned in the eukaryotic expression vector pcDNA3, associated or not to the Kozak sequence. Plasmid DNA of the two versions of the vaccine candidate was inoculated in mice by the intramuscular route, in two doses, at 0 and 21 days. The animals that received the DNA vaccine containing faeC associated to the Kozak sequence presented seroconversion significantly higher $(\mathrm{P}<0.05)$ than the one vaccinated with pcDNA3/faeC without the Kozak sequence.
\end{abstract}

Key words: swine colibacilosis, DNA vaccine, faeC, Kozak sequence.

\section{INTRODUCTION}

Swine neonatal diarrhea caused by enterotoxigenic Escherichia coli (ETEC) is responsible for important economical losses due to high mortality and low growth rate of pigs (1). The ability of the bacterium to cause disease is mainly dependent on the capacity of $E$. coli to attach to the surface of the small intestine, a property mediated by fimbria (3). Among other antigenic fimbria, K88 is the most prevalent in the South of Brazil (4) and it is encoded by an eight gene operon (3). The protein encoded by faeC is the minor fimbral subunit which is located at the tip of the fimbria, and therefore might be important for the fimbrial adhesive characteristics (5).

DNA vaccines appear as a new strategy to veterinary diseases control. This vaccines consist of a plasmid containing the gene that encodes for the antigen. Among other features, it is necessary an efficient antigen expression in the cell in order to elicit a protective immune response. Studies involving eukaryotic genes demonstrated that the Kozak sequence, which consists of a guanine at position +4 and an adenine at -3 from the start codon, increases the efficiency of translation of the gene $(6,7)$. In this study we associated the Kozak sequence to the faeC gene, in a DNA vaccine, and evaluated the immune response in mice.

\section{MATERIALS E METHODS}

The $f a e \mathrm{C}$ gene was amplified by PCR from an E. coli $\mathrm{K} 88$ strain and clone into pcDNA3 resulting in a plasmid named pcDNA3/faeC. A second version of the gene was made using a modified forward primer in order to include the Kozak sequence, which was also cloned into pcDNA3 resulting in a plasmid named pcDNA3/faeC/Kozak. This plasmids were produced in large scale, purified using the GigaPrep kit

*Corresponding author. Mailing address: Universidade Federal de Pelotas. Campus Universitário Capão do Leão. 96010-900, Pelotas, RS, Brazil. Tel.: (+5553) 281-3365. E-mail: amichelon.fv@ufpel.tche.br 
(Qiagen) and concentrated to $1 \mu \mathrm{g}$ of DNA/ $\mu \mathrm{L}$. Mice were divided into 4 groups containing 5 animals each group. Mice age ranged from 5 to 7 weeks and they were injected with pcDNA3, pcDNA3/faeC, pcDNA3/faeC/Kozak or saline (control group), respectively. Mice received $100 \mathrm{ng}$ of DNA intramuscularly at days 0 and 21 . Thirty minutes before vaccination, they received $50 \mu \mathrm{L}$ of a $25 \%$ saccharose solution in the same place. Blood samples were collected from the retroocular plex every 21 days, starting at day 0 . The serum obtained was evaluated by ELISA, in order to determine the immune response against faeC. ELISA plates were sensitized with recombinant $\mathrm{FaeC}$ protein.

\section{RESULTS AND DISCUSSION}

Amplification of the two versions of the $f a e C$ gene was successful, as well as the cloning into pcDNA3. The presence of BamHI and HindIII sites at the end of the amplified fragments facilitated the direct cloning of the amplified products into the pcDNA3, resulting in plasmids named pcDNA3/faeC for the one containing the original coding sequence of faeC, and pcDNA3/faeC/Kozak for the one containing the modified version of faeC, incorporating the Kozak sequence. Fig. 1 shows the release of the faeG gene after digestion with the two restriction enzymes used in the cloning process.

Fig. 2 demonstrates the seroconversion of the animals after vaccination. Seroconversion of the group vaccinated with pcDNA3/faeC/Kozak was higher and statistically different $(p<0,05)$ from the other groups through the study (21, 42 and 63 days). The groups vaccinated with saline, pcDNA3 or pcDNA3/faeC did not show any statistical difference from each other. These results highlight the positive

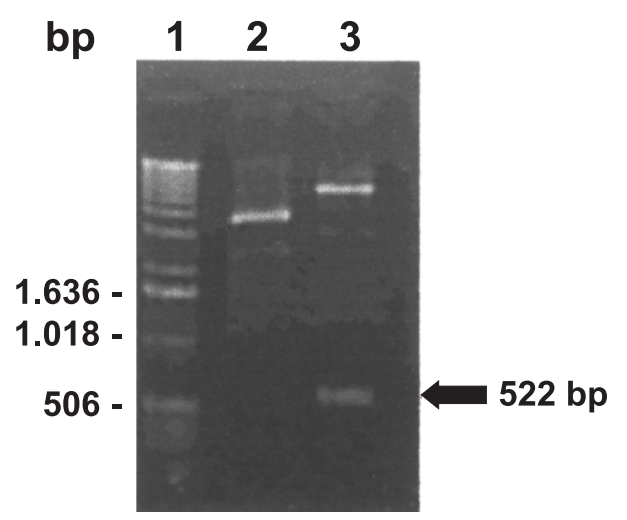

Figure 1. Agarose gel electrophoresis of pcDNA3/faeC/ Kozak. Lane 1: $1 \mathrm{~kb}$ DNA Ladder (Invitrogen); lane 2: undigested plasmid DNA; Lane 3: pcDNA3/faeC/Kozad digested with BamHI and HindIII, releasing faeC/Kozak gene (522 bp).

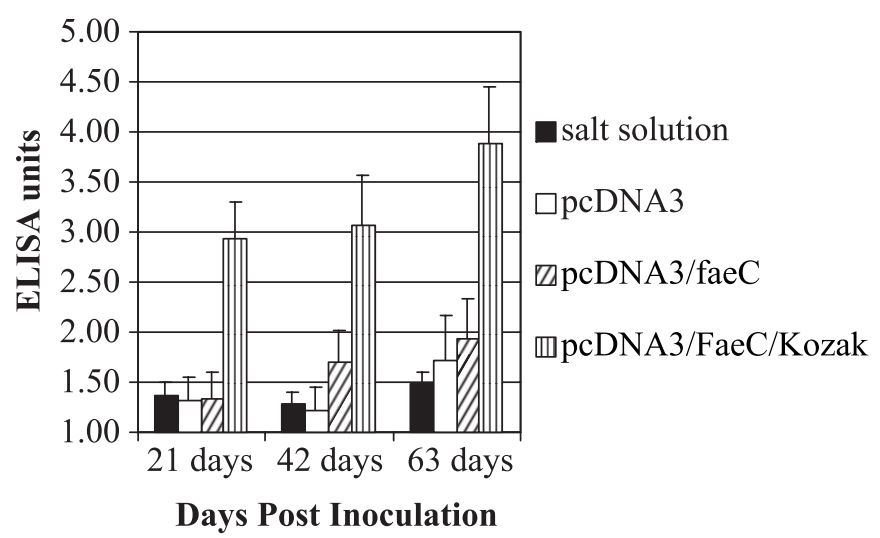

Figure 2. Seroconversion of mice immunized with the different vaccine constructions.

influence of Kozak sequence in a DNA vaccine against swine colibacilosis, using the $\mathrm{fae} C$ gene, whose vaccinated group showed better seroconversion results. Many DNA vaccine studies have been performed with bacterial antigen genes, without taking into account the fact that the lack of the Kozak sequence, absent in prokaryotic genes, may hinder the expression of the gene in eukaryotic cells (2). Better results might have been obtained if the Kozak sequence had been added to the gene, as demonstrated in this work with the faeC gene.

\section{RESUMO}

\section{Efeito da sequência de Kozak na soroconversão de camundongos imunizados com uma vacina de DNA contra a colibacilosa suína}

A diarréia neonatal em suínos causada por Escherichia coli produtora de enterotoxinas (ETEC) é responsável por alta mortalidade e baixa taxa de crescimento de leitões. A habilidade de tais cepas causar doença é dependente principalmente da capacidade de E. coli aderir-se a mucosa do intestino delgado, que é mediada por fímbrias. Neste estudo o gene faeC, que codifica a subunidade menor da fímbria de E. coli K88ab, foi clonado no vetor de expressão em eucariotos pcDNA3, associado ou não à seqüência de KozaK. DNA plasmidial das duas versões da vacina foi inoculado em camundongos via intramuscular, em duas doses, nos dias 0 e 21 . Os animais que receberam a vacina de DNA contendo o faeC associado a seqüência de Kozak apresentaram soroconversões significativamente maiores $(\mathrm{p}<0,05)$ que os vacinados com pcDNA3/faeC sem a seqüência de Kozak.

Palavras-chave: colibacilose suína, vacina de DNA, faeC, seqüência de Kozak. 


\section{REFERENCES}

1. Straw, B.E.; D’Allaire, S.; Mengeling, W.L.; Taylor, D.J. Diseases of swine. Antarct. Sci. $8^{\text {th }}$ edition, 1999.

2. Turner, C.G.; Aleixo, J.A.; Monteiro, A.V.; Dellagostin, O.A. DNA inoculation with a plasmid vector carrying the faeG adhesin gene of Escherichia coli K88ab induced immune responses in mice and pigs. Vaccine., 9:2089-2095, 1999.

3. Oudega, B.; Graaf, F.K. Genetic organization and biogenesis of adhesive fimbria of Escherichia coli. Antonie van Leeuwenhoek. 54:285-299, 1988.

4. Sobestiansky, J.; Barcellos, D.; Mores, N.; Carvalho, L.F.; Oliveira, S.; Moreno, A.M.; Roehe, P.M. Patologia e clínica suína. Art 3 Impressos especiais, Goiânia, 1999.
5. Sun, R.; Anderson, T.J.; Erickson, A.K.; Nelsaon, E.A.; Francis, D.H.; Inhibition of adhesion of Escherichia coli K88ac to its receptor, intestinal mucin type glycoproteins, by a monoclonal antibody directed against a variable domain of the fimbria. Infect. Immun., 68(6):3509-15, 2000.

6. Kozak, M. Possible role of flanking nucleotides in recognition of the AUG initiator codon by eukaryotic ribosomes. Nucleic Acids Res., 9:5233-5262, 1981.

7. Kozak, M. Point mutations define a sequence flanking the AUG initiator codon that modulates translation by eukaryotic ribosomes. Cell., 44:283-292, 1986 